\section{Case Reports in Dermatology}

Case Rep Dermatol 2017;9:151-157

DOI: 10.1159/000480068

Publisned onlıne: September 11, 2017

This article is licensed under the Creative Commons Attribution-NonCommercial 4.0 International License (CC BY-NC) (http://www.karger.com/Services/OpenAccessLicense). Usage and distribution for commercial purposes requires written permission.

\title{
Pachyderma in Primary Cutaneous NK and T-Cell Lymphoma and Leukemia Cutis
}

\author{
Eve Lebas $^{\mathrm{a}}$ Cesar Chian $^{\mathrm{c}}$ Nazli Nikkels-Tassoudji ${ }^{\mathrm{a}} \quad$ Jorge E. Arrese ${ }^{\mathrm{b}}$ \\ Arjen F. Nikkels ${ }^{a}$ \\ ${ }^{a}$ Department of Dermatology, Liège University Hospital, Liège, Belgium; ${ }^{b}$ Department of \\ Dermatopathology, Liège University Hospital, Liège, Belgium; ${ }^{C}$ Department of Pathology, \\ Hospital Arzobispo Loayza, Lima, Peru
}

\section{Keywords}

Pachyderma $\cdot$ Mycosis fungoides $\cdot$ Cutaneous T-cell lymphoma

\begin{abstract}
Background: Pachyderma is defined as severely thickened skin with deep folds and is occasionally observed with primary cutaneous NK and T-cell lymphoma (pCNKTCL), primary cutaneous B-cell lymphoma ( $\mathrm{pCBCL}$ ), and leukemia cutis (LC). Aim: To describe the clinical, histological, and therapeutic particularities of a series of $\mathrm{pCNKTCL}, \mathrm{PCBCL}$, and $\mathrm{LC}$ patients with pachyderma. Results: In a series of pCNKTCL $(n=70), \mathrm{pCBCL}(n=12)$, and LC $(n=2)$ patients followed up during 9 years, 6 cases of pachyderma were observed. Pachyderma occurred on the arms $(n=2)$, thighs $(n=1)$, forehead $(n=1)$, and face $(n=2)$. The mean age of the patients was 69 years (51-82). The stages were erythrodermic (T4) mycosis fungoides (MF) $(n=1)$, folliculotropic MF (FMF) $(n=2)$, classic (T2) MF $(n=2)$, and chronic myeloid leukemia $(n=1)$. The erythrodermic MF patient with acute pachyderma on the right arm responded rapidly to oral steroids. The other cases were indolent, appeared progressively, and were highly treatment resistant. Histology revealed dense dermal neoplastic infiltration.
\end{abstract}


The immunohistological profile of the pachydermic lesions was similar to common MF and LC. Conclusion: Pachyderma is an atypical manifestation of MF and LC and may occur on the face (FMF) or the extremities (MF). The rapidly appearing pachyderma may be transitory and responds readily to oral steroids.

(C) 2017 The Author(s)

Published by S. Karger AG, Basel

\section{Introduction}

Pachyderma is defined as substantially thickened skin with deep folds, as observed in pachyderm animals such as elephants, rhinoceros, and hippopotami. Pachyderma in humans may be observed in several medical conditions - among others, during chronic severe lymphatic insufficiency with lymphedema [1], pachydermoperiostosis (Touraine-Solente-Golé syndrome) [2], keratitis-ichthyosis-deafness syndrome [3], congenital or secondary cutis verticis gyrata [4, 5], crusted scabies [6], severely infiltrated scleromyxedema [7], especially of the face, and lepromatous leprosy, presenting as leonine facies. White sponge nevus is considered a manifestation of pachyderma of the intraoral mucosa.

Mycosis fungoides (MF) is the most frequently encountered manifestation of primary cutaneous NK and T-cell lymphoma (pCNKTCL). Leukemia cutis (LC) is a nonspecific term used for cutaneous manifestations of any type of leukemia. Pachyderma occurring in patients with pCNKTCL [8] and LC [9, 10] has exceptionally been reported. Pachyderma in pCNKTCL patients classically presents as leonine facies and seems restricted to patients with facial folliculotropic MF (FMF) [11]. Leonine facies has also been described in a patient suffering from chronic primary cutaneous B-cell lymphoma (pCBCL) [12].

The mechanisms and clinical patterns of pachyderma during pCNKTCL and LC are not well elucidated. The aim of this study was to describe the clinical particularities as well as the histological and therapeutic features in a series of pCNKTCL, PCBCL, and LC patients presenting with pachyderma.

\section{Subjects and Methods}

The study was performed in accordance with the Declaration of Helsinki (version 2013). The institutional ethics committee approved the design of the study. The patients were informed about the procedures and were invited to fill in a medical questionnaire. All the patients signed the informed consent forms.

A cohort of 84 patients with pCNKTCL $(n=70)$, pCBCL $(n=12)$, or LC $(n=2)$ were included and prospectively followed up during 9 years. In this patient series, the number of patients with pachyderma was assessed. Pachyderma was defined as the presence of thick continuous and concatenated skin folds with prominent convexities and furrowed creases. Age, gender, the anatomical site, the extension and duration of the pachydermic lesions, the underlying disease stage, the pachydermic disease course, and the treatments were recorded for all the cases with pachyderma. A skin biopsy was performed on all pachyderma patients under local anesthesia for histological and immunohistological assessments as well as for PCR to search for monoclonal TCR rearrangement. 


\section{Results}

Among the 84 patients, 6 fulfilled the above-mentioned criteria for pachyderma during the observation period. The anatomical sites were the arms $(n=2)$, buttocks $(n=1)$, forehead $(n=1)$, and face $(n=2)$. The mean age of the pachyderma patients was 69 years (min. 51, max. 82). The disease stages at the moment of diagnosis of pachyderma were erythrodermic (T4 stage) MF ( $n=1)$, FMF ( $n=2)$, classic type (T1/2 stage) MF ( $n=2)$, and chronic myeloid leukemia $(n=1)$. All the MF and FMF patients had a long disease history of pCNKTCL. The extension of the pachyderma of the face and forehead corresponded precisely to the skin area involved in FMF and LC. In contrast, the pachyderma on the extremities only involved part of the total cutaneous extension seen in MF. The pachydermic infiltration of the arms appeared quickly and rapidly responded to oral steroids (Fig. 1). In contrast, the lesions of the buttocks and the face (Fig. 2) were indolent, appeared progressively, and were highly treatment resistant. The histological examination (Fig. 1, 2) of the pachydermic lesions revealed a dense inflammatory and neoplastic infiltrate of the entire dermis with extension to the epidermis and sometimes the hypodermis, but this was otherwise not different from common MF, FMF, and myeloid LC (MLC). The immunohistological profile revealed a dense $\mathrm{CD} 3+, \mathrm{CD} 4+, \mathrm{CD} 45 \mathrm{R} 0+$, and CD8-infiltrate (Fig. 2). In all the MF and FMF cases, TCR monoclonality was observed by PCR. This monoclonality was identical to that previously evidenced during the initial workup at diagnosis. In the MLC patient, a dense myeloid infiltrate of the dermis was noted (Fig. 2). The individual patient data are presented in Table 1.

The rapid appearance of the pachyderma on the arms (Fig. 1) encouraged the use of systemic oral steroids (methylprednisolone, $125 \mathrm{mg}$ progressively tapered over 2 weeks) and was followed by total regression of the pachydermic aspect (Fig. 1).

\section{Discussion}

Besides classic MF, an important array of atypical MF presentations are encountered, including FMF and syringotropic, verrucous, bullous, vesicular, pustular, granulomatous, alopecic, palmoplantar, unilesional, "tumeur d'emblée"-type, poikilodermic, hypopigmented, hyperpigmented, interstitial, papillomatous, ichthyosiform, mucosal, and pigmented purpuric MF $[8,13,14]$. Transitions from one form to another and coexistence of different forms may be observed. Hence, it is not without reason that MF is often called the great mimicker $[8,13,14]$.

A slow-appearing and chronic form of pachyderma (leonine facies) may be encountered in patients suffering from FMF of the face [11]. It appears as hypertrophy and progressive folding of the facial skin, in particular the forehead. FMF-associated leonine facies is observed in stage IV cutaneous T-cell lymphoma and is often accompanied by some degree of blood involvement. Treatment with local electron beam therapy was recommended [11].

Although the clinical picture of pachyderma is relatively unequivocal, there is no clear histological definition of pachyderma, as the thickening may have various origins. Tumoral infiltration of neoplastic lymphocytes seems the main reason for pachyderma in FMF [11] and MF, tumoral infiltration of leukemic cells in LC [15], granulomatous infiltration in the case of leprosy, lymphatic and edematous stowage in patients with lymphatic insufficiency 
[1] or scleromyxedema [7], and dense lymphocytic infiltration in the case of prurigo and Norwegian scabies [6]. Granulomatous slack skin may also present a pachydermic aspect, particularly in the skin folds. The folds are caused by a granulomatous infiltration of the dermis by atypical lymphocytes. The folds are even more accentuated due to enzymatic degradation of the elastic fibers, enzymes released by tumoral cells $[12,13]$. The two cases of pachyderma affecting the face are similar to the description of FMF-associated leonine facies [11].

In conclusion, chronic and transitory forms of pachyderma on the extremities may be encountered in patients with long-standing MF and should be recognized as one of the manifestations of MF. Oral steroids seem to represent a beneficial therapeutic option in rapidly appearing pachyderma. Chronic pachyderma on the face is associated with facial involvement of FMF.

\section{Statement of Ethics}

Ethics approval was obtained.

\section{Disclosure Statement}

The authors have no conflicts of interest to disclose. There was no funding for this work.

\section{References}

1 Raty L, Failla V, Andrianne R, Fillet M, Waltregny D, Nikkels AF: Chronic idiopathic penile edema: three cases and a review of the literature. Open Dermatol J 2011;5:1-5.

-2 Supradeeptha C, Shandilya SM, Vikram Reddy K, Satyaprasad J: Pachydermoperiostosis - a case report of complete form and literature review. J Clin Orthop Trauma 2014;5:27-32.

- J Jonard L, Feldmann D, Parsy C, Freitag S, Sinico M, Koval C, Grati M, Couderc R, Denoyelle F, Bodemer C, Marlin S, Hadj-Rabia S: A familial case of keratitis-ichthyosis-deafness (KID) syndrome with the GJB2 mutation G45E. Eur J Med Genet 2008;51:35-43.

4 Larsen F, Birchall N: Cutis verticis gyrata: three cases with different aetiologies that demonstrate the classification system. Australas J Dermatol 2007;48:91-94.

-5 Harding JJ, Barker CA, Carvajal RD, Wolchok JD, Chapman PB, Lacouture ME: Cutis verticis gyrata in association with vemurafenib and whole-brain radiotherapy. J Clin Oncol 2014;32:e54-e56. Khera P, English JC: Images in clinical medicine. Pachyderma. N Engl J Med 2009;361:e29. Chockalingam R, Duvic M: Scleromyxedema: long-term follow-up after high-dose melphalan with autologous stem cell transplantation. Int J Dermatol 2016;55:e539-e543.

-8 Jawed SI, Myskowski PL, Horwitz S, Moskowitz A, Querfeld C: Primary cutaneous T-cell lymphoma (mycosis fungoides and Sézary syndrome): part I. Diagnosis: clinical and histopathologic features and new molecular and biologic markers. J Am Acad Dermatol 2014;70:205.e1-e16; quiz 221-222.

-9 Cho-Vega JH, Medeiros LJ, Prieto VG, Vega F: Leukemia cutis. Am J Clin Pathol 2008;129:130-142.

10 Cronin DM, George TI, Sundram UN: An updated approach to the diagnosis of myeloid leukemia cutis. Am J Clin Pathol 2009;132:101-110.

-11 Brown DN, Wieser I, Wang C, Dabaja BS, Duvic M: Leonine facies (LF) and mycosis fungoides (MF): a single-center study and systematic review of the literature. J Am Acad Dermatol 2015;73:976-986.

12 Cerroni L, Gatter K, Kerl H: An Illustrated Guide to Skin Lymphoma, ed 2. Oxford, Blackwell, 2004, chapter 14, pp 120-130. 


\section{Case Reports in Dermatology}

Case Rep Dermatol 2017;9:151-157
\begin{tabular}{l|l}
\hline DOI: $10.1159 / 000480068$ & $\begin{array}{l}\text { @ 2017 The Author(s). Published by S. Karger AG, Basel } \\
\text { www.karger.com/cde }\end{array}$
\end{tabular}

Lebas et al.: Pachyderma in Primary Cutaneous NK and T-Cell Lymphoma and Leukemia Cutis

13 Howard MS, Smoller BR: Mycosis fungoides: classic disease and variant presentations. Semin Cutan Med Surg 2000;19:91-99.

-14 Abeldaño A, Arias M, Benedetti A, Ochoa K, Maskin M, Pellerano G, Kien MC, Chouela E: Unusual variants of mycosis fungoides. Skinmed 2011;9:218-222.

15 Passarini B, Neri I, Patrizi A, Masina M: Cutis verticis gyrata secondary to acute monoblastic leukemia. Acta Derm Venereol 1993;73:148-149.
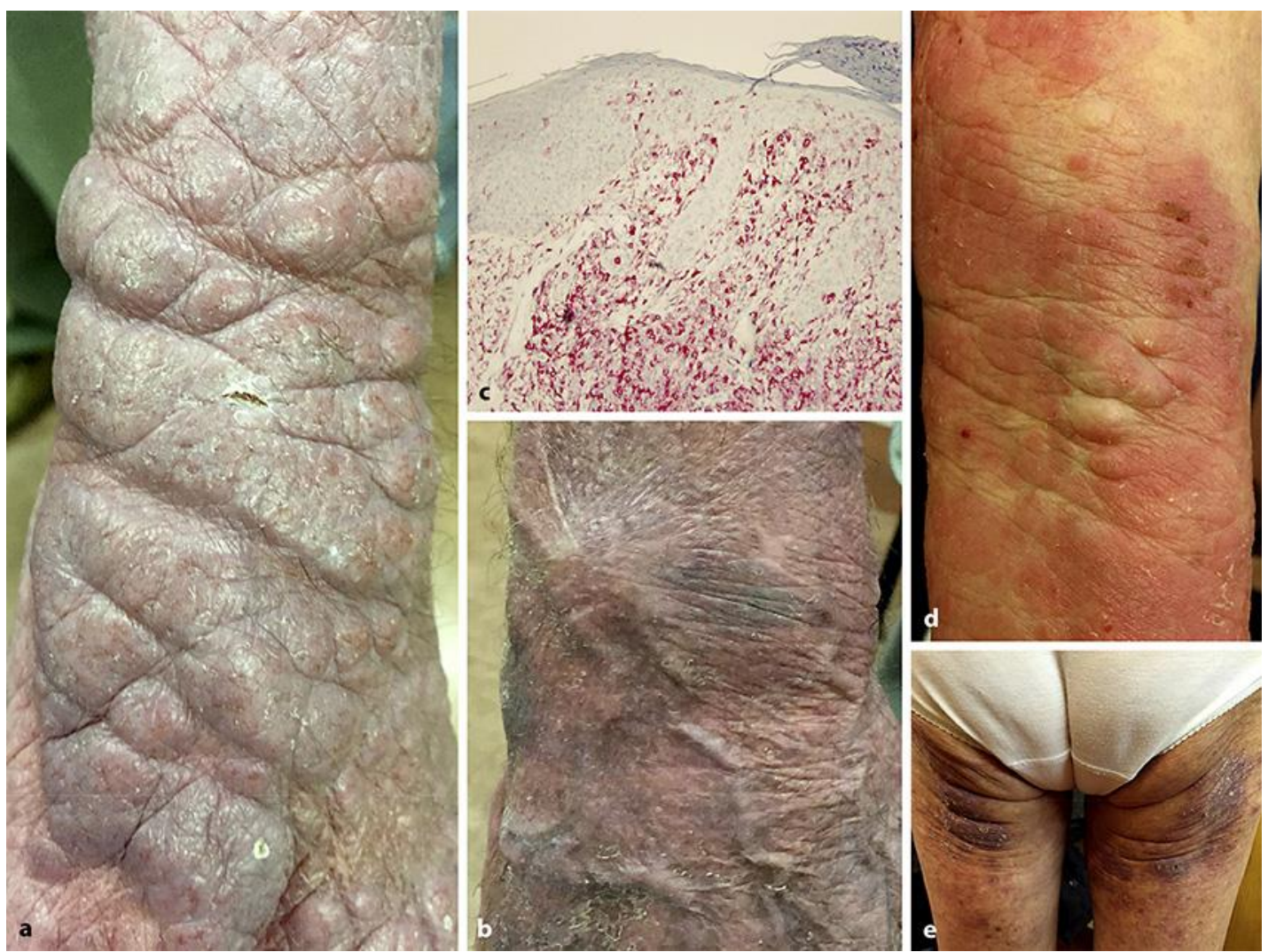

Fig. 1. a Pachyderma on the right arm. b Three weeks after treatment with oral steroids. c CD4+ rich and dense dermal infiltrate of atypical lymphocytes. $\mathbf{d}$ Pachyderma on the arm. e Bilateral pachyderma on the thighs. 


\section{Case Reports in Dermatology}
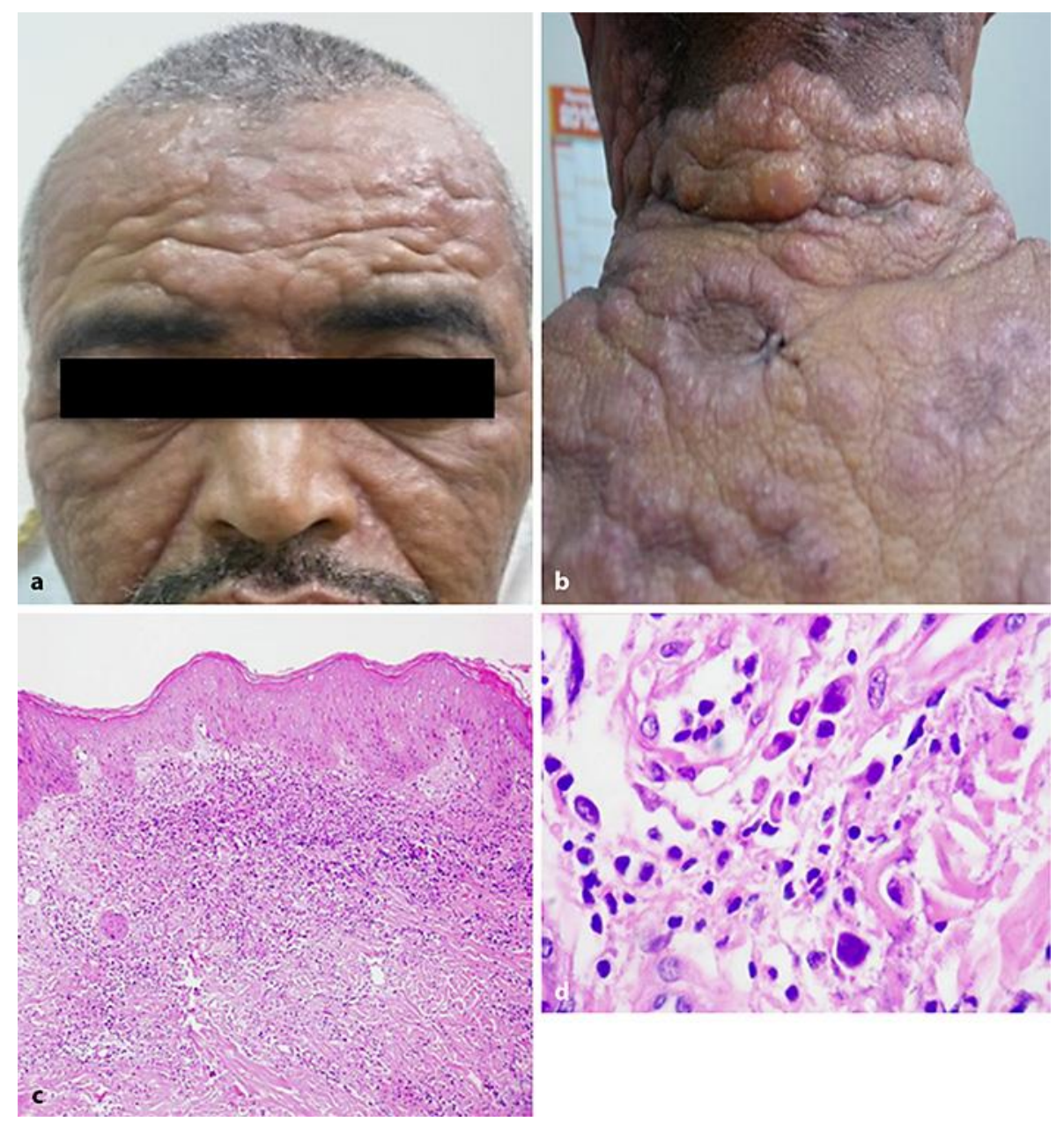

Fig. 2. a Pachydermic infiltration of the forehead of the patient with myeloid leukemia cutis. b Pachyderma on the neck and in the shoulder area of the same patient. c Dense myeloid infiltrate extending over the entire dermis and infiltrating the hypodermis. $\mathbf{d}$ High-power view of leukemic cells in the dermis. 
Table 1. Pachyderma patient demographics

\begin{tabular}{|c|c|c|c|c|c|c|}
\hline $\begin{array}{l}\text { Case } \\
\text { No. }\end{array}$ & $\begin{array}{l}\text { Age, } \\
\text { years/ } \\
\text { gender }\end{array}$ & Diagnosis & $\begin{array}{l}\text { TNMB/FAB } \\
\text { stage }\end{array}$ & $\begin{array}{l}\text { Anatomical } \\
\text { site }\end{array}$ & $\begin{array}{l}\text { Pachyderma } \\
\text { course }\end{array}$ & $\begin{array}{l}\text { Treatment of } \\
\text { pachyderma }\end{array}$ \\
\hline 1 & $64 / F$ & FMF & $\begin{array}{l}\text { T1N0M0B0/ } \\
\text { IA }\end{array}$ & Front & Chronic & Photodynamic treatment \\
\hline 2 & $82 / \mathrm{M}$ & MF & $\begin{array}{l}\text { T4N1M0B0/ } \\
\text { III }\end{array}$ & Right arm & Transient & Oral steroids, MTX \\
\hline 3 & $80 / \mathrm{F}$ & MF & $\begin{array}{l}\text { T2N0M0B0/ } \\
\text { IB }\end{array}$ & Left arm & Chronic & Interferon + MTX \\
\hline 4 & $51 / \mathrm{M}$ & MLC & FAB M2 & $\begin{array}{l}\text { Face, neck, } \\
\text { shoulders }\end{array}$ & Chronic & $\begin{array}{l}\text { Deceased } 4 \text { months after } \\
\text { diagnosis }\end{array}$ \\
\hline 5 & $62 / \mathrm{M}$ & FMF & $\begin{array}{l}\text { T2N0M0B0/ } \\
\text { IB }\end{array}$ & Face & Chronic & Retinoids, RxT \\
\hline 6 & $74 / F$ & $\mathrm{MF}$ & $\begin{array}{l}\text { T2N0M0B0/ } \\
\text { IB }\end{array}$ & Buttocks & Chronic & Topical steroids, MTX, RxT \\
\hline
\end{tabular}

MF, mycosis fungoides, classic type; FMF, folliculotropic MF; MLC, myeloid leukemia cutis; FAB M2, FrenchAmerican-British classification, acute myeloblastic leukemia with maturation; TNMB, tumor, node, metastasis, blood; MTX, methotrexate; RxT, radiation therapy. 